\title{
Nezvalova gotická i surrealistická Valérie
}

\author{
Bohumil Fořt
}

\begin{abstract}
Gothic and Surrealistic Valérie by Nezval

Valerie and Her Week of Wonders (1932) by Vítězslav Nezval represents a unique attempt of merging the tradition of the Gothic novel with modern Czech avant-garde literature. Valerie and Her Week of Wonders is examined in detail with regards to both contexts (and not only to them). The study reveals and interprets specific poetic devices, both formal and thematic, used by the author in order to distort the poetics of the Gothic novel to an extent that it can be metamorphized into a fully surrealist literary artwork.
\end{abstract}

\section{KEYWORDS}

Gothic novel, surrealism, Valerie and Her Week of Wonders, Vítězslav Nezval, parody, dream.

\section{KLÍčOVÁ SLOVA}

Gotický román, surrealismus, Valérie a týden divů,Vítězslav Nezval, parodie, sen.

Valérie a týden divů (1932) je pro literárního badatele vděčným textem - především díky svým zřetelným a přiznaným souvislostem $s$ jinými texty, směry a tradicemi, $\mathrm{k}$ nimž více či méně explicitně odkazuje. ${ }^{1} \mathrm{Z}$ nich nejsilnější jsou samozřejmě ty spojené s tradicí gotického románu, frenetické literatury či romantické fantastiky na jedné straně a se surrealistickou motivikou a strategiemi textové výstavby na straně druhé - přičemž toto konstatování samozřejmě nevylučuje vzájemné souvislosti obou tradic. Cílem této studie je tedy ukázat, jak se v tomto konkrétním díle obě tradice setkávají, jak se za pomoci specifických

1) Dalibor Tureček sice pochopitelně nahlíží intertextové odkazy Valérie na úrovni celých literárních žánrů a typů, ovšem možnost nalézat $\mathrm{v}$ textu odkazy ke konkrétním literárním dílům, která tyto žánry a typy reprezentují, je (nejenom) čtenářsky atraktivní (srov. TUREČEK 2006: 803). 
prostředků poetika gotického románu mistrně transformuje v poetiku surrealistickou, a to na různých úrovních formální a významové výstavby celého díla.

Klíč k mému uchopení Valérie se bude do značné míry odvíjet od konkrétního autorského záměru, s nímž nás Vítězslav Nezval přímo seznamuje ve své předmluvě ke knize samé: „Napsal jsem tuto knihu z lásky k tajemství starých vypravovánek, pověr a romantických knih, psaných švabachem [...]. Aniž bych chtěl svým, Černým románem ' kohokoliv sváděti z cesty (nejméně ty, kdož se bojí pohledět přes hranice ,dneška'), obracím se k těm, kdož se občas rádi zastavují jako já nad mystériem určitých dvorů, sklepení, letohrádků a smyček mysli kolem tajemného. Podám-li jim touto knihou evokaci jistých vzácných a řídkých pocitů, které mne přiměly $\mathrm{k}$ napsání příběhu, který klepe na okraj směšného a bezcenného, budu spokojen“ (NEZVAL 1971 [1932]: 7; kurzíva BF). Nezval explicite nazývá svou knihu „Černým románem“ - ovšem co značí ony uvozovky? Jistě není složité je interpretovat v souvislosti s textem samým: pokud by Valérie opravdu byla černým románem, byla by velice netypickou reprezentantkou tohoto žánru: jakkoli k černým (či gotickým) románům přímo blatantně odkazuje hned na několika úrovních své (vý)stavby, ve skutečnosti je praktickou ukázkou zřetelné parodie na tento literární podžánr. Podívejme se tedy na to, jakými prostředky je ve Valérii tato parodičnost pěstována, a na to, jak se tyto prostředky podílejí na celkovém vyznění tohoto atypického románu

Nezval v předmluvě mluví o mysteriózních dvorech, sklepeních a letohrádcích - klasických to proprietách z množiny sakrálních či aristokratických kulis gotického románu a nedílných součástí jeho významové výstavby, z nichž sám některé využívá, ovšem vzápětí tyto exteriéry a interiéry umistuje hned vedle kurníku, hospodského lokálu či neotesané manželské ložnice na statku - oddělení profánního a sakrálního, známého a neznámého, přirozeného a nadpřirozeného, tak časté $\mathrm{v}$ gotických exteriérech, je tak zcela porušeno, svět Valérie připomíná amorfní agregát, neustále se proměňující a unikající konceptualizaci čtenářem.

Avšak i další propriety gotického románu jsou ve Valérii bud’to umístěny do nezvyklých juxtapozic, či jsou přímo deformovány. Především je to rozsah vyprávěného času: zatímco gotické romány se zpravidla odehrávají v rocích a dekádách, ${ }^{2}$ Valérie se odehrává v času málo překračujícím sedm dnů. Ovšem

2) Je zřejmé, že historicita, tedy jistý nekrátký úsek zobrazovaného časového období, je esenciálním prostředkem výstavby gotického románu či romantické romance: historicita je důležitou bází pro produkci příběhů s tajemstvím, které může být odhaleno pouze v souvislosti s „dávnou“ historií, s událostmi, které se odehrály před tak dlouhou dobou, že upadly (nebo téměř upadly) v zapomnění. 
zároveň je třeba uvést, že co se týče jiných temporálních charakteristik Valérie, časové výstavbě gotického románu (či romantické romance) zcela odpovídají: jsou to především konkrétní analeptické techniky sloužící k postupnému odkrývání zápletky, které vrcholí, naprosto v souladu s romantizující výstavbou syžetu, v samém závěru celého příběhu. A opět, stejně jako je narušena prostorovost Valérie, je i její časovost podivným způsobem deformována - časové deformace, v gotickém románu přináležející spojením s nadpřirozenem, jsou zde všudypřítomné, prostupují románem jako prostředky narušující klasickou narativní časovost nezbytnou pro čtenářské uchopení odehrávajícího se př́běhu.

Dalším z přetvořených a zároveň parodovaných motivů gotického románu ve Valérii je zjevení, přízrak či duch, nezbytný aktér gotických akcí, fungující zpravidla bud’ jako emisar, nebo přímo zástupce nadpozemských mocností. Ovšem tento nemá ve Valérii jakoukoli supernaturální funkci a je přiřazen primitivnímu chápání reálné skutečnosti - slepičímu moru. ${ }^{3}$

Krev, hnací kapalina pístů gotických dějů zpravidla doprovázející uzlové body jejich zápletek, vraždy, souboje, obětování či mučení, je ve Valérii, kromě jiného, tematizována jako krev menstruační či jako krev slepičí sloužící jako potrava hlavnímu negativnímu hrdinovi, Tchoři, typickému škůdci - přirozenému i proppovskému, plnícímu jasně stanovenou roli v rámci rozvrhu celého příběhu a vykonávajícímu příslušné aktivity.

$Z$ výše uvedeného výčtu je tedy, doufám, dostatečně zřejmé, že tradiční „černé“ je v Nezvalově románu v rámci jeho parodování kombinováno s nečekanými, ${ }^{4}$ tuto „černost“ spíše podrývajícími motivy a elementy, což posiluje absurditu či směšnost celého spojení. Ovšem tato kombinace, zasahující celkovou výstavbu románu, kromě absurdity založené na parodii klasického žánru, má zároveň zásadní vliv na deformaci časové a prostorové integrity textu a příběhu, která má zásadní vliv na čtenářskou konceptualizaci celého světa a příběhu: gotické reálno vs. nereálno přechází v nezvalovské surreálno.

3) Je zřejmé, že chápání moru (či obecně nějaké fatální infekční nemoci) jakožto přízraku se objevuje již ve stř̌edověké a raně novověké „mytologii“ Evropy, nicméně tento motiv se v gotických románech obvykle nevyskytuje. Př́izraky gotických románů, byṫ mohou mít podobně mlžnou podobu, jako je tomu u představ o moru a jako je tomu ostatně i ve Valérii, reprezentují duchy zemřelých lidí či posly nebeských či pekelných mocností. Tito poslové pak, na rozdíl od mlhavosti moru, nabývají zcela zřetelných podob. Nejzřetelnějším příkladem takového zpodobení jsou různá zjevení dábla v Lewisově Mnichovi. Za všechny uved’me popis jeho konečné podoby: „Jeho sežehlé údy dosud nesly stopy blesků Všemohoucího. Celá jeho gigantická postava byla temně osmahlá a na rukou i na nohou měl dlouhé drápy. Oči mu blýskaly zư̌rivostí, která by zastrašila i to nejstatečnější srdce..." (Lewis 1971 [1795]: 505).

4) André Breton tento druh textové výstavby zřetelně vyznačuje v rámci surrealistické poetiky a uvádí, že: „Všechno je dobré $\mathrm{k}$ tomu, aby se od jistých asociací dosáhlo žádoucí nenadálosti““(BREToN 2005 [1924]: 57). 
Pokud jsem dosud odkazoval k obecným motivưm a strategiím, kterými Valérie souvisí s gotickými romány, $v$ případě její konatelské sestavy je možné mluvit doslova o protějšcích konkrétních postav těchto románů - a to přestože Nezval opět hojně využívá kombinace těchto gotických prostředků s prostředky, tak řečeno, „negotickými“. Jakkoli je Valérie typicky gotickou cudnou pannou, která je součástí dějů, jež začaly dlouho před jejím narozením a které ji vystavují výjimečným situacím a nutí ji k těmto situacím zaujmout (obecně lidský či morální) postoj, je zároveň „dívkou odvedle“, zasněnou Alenkou, které se okolní svět i vlastní tělo proměňuje v erotickou a sexualizovanou Říši divů. V návaznosti na gotickou tradici je Valérie jistě ústřední postavou celého románu, ovšem v návaznosti na stejnou tradici není jeho hlavní akční (či aktivní) postavou. Tou je bezesporu Tchoř. Kdo je však Tchoř? Goticky nesmrtelný Ahasver, učený doktor Faust, tajemný Velký Mogul s nadpozemskými schopnostmi z Mnicha či krutý džaur svádějící lidi bez víry (včetně Vatheka) do pekla zatracení. Zároveň ovšem je i Mnichem-Ambrosiem, který se pokouší zneuctít neposkvrněnou pannu, kazatelem svérázným způsobem sexualizujícím Píseň písní, Manfrédem-synovrahem z Otrantského zámku, který jen náhodou nedokonává svůj čin. Tchoř je však i lidským monstrem se zvířecí tváří živícím se slepičí krví, Richardem - původním majitelem Valériina domu a babiččiným milencem, hospodským povalečem a rváčem a konečně tchořem zastřeleným u kurníku sluhou Ondřejem jakožto škodná. Základní sestavu hlavních postav dokreslují Orlík a babička. A znovu, Orlík je Edmundem Starého anglického barona i Teodorem z Otrantského zámku, dobrým sluhou špatného pána, Valériiným poradcem a ochráncem, který je do ní ovšem zamilován a pokouší se ji svést. Babička je pak postavou vskutku dvojakou (vlastně trojakou): je pečující a mírumilovnou vychovatelkou Valériinou, omlazenou Elsou s vysokým sexuálním apetitem, kvůli kterému je ochotna se Valérie jakožto sokyně zbavit, a nakonec i krkavčí matkou, která kvůli žárlivosti vyhání z domu a opakovaně odvrhává vlastní dceru. Nicméně prakticky každý vztah mezi členy této „hlavní čtyřky“ má nějaký sexuální rozměr - vzhledem ke skutečnému či domnělému př́ibuzenství těchto postav je zřejmé, že se zčásti jedná o sexualitu incestní.

V tradici gotického románu se samozřejmě setkáváme s podobně komponovanými konstelacemi: neznámý či zamlčený původ, častý prostředek romantizující gotické zápletky, může vést $\mathrm{k}$ incestním sexuálním vztahům, ale ovšem i k vraždám mezi rodinnými příslušníky, případně k obojímu. Ovšem rozdíl mezi gotickým románem, kde taková situace vede, zcela podle pravidel antického dramatu, k nevyhnutelné katastrofě, ve Valérii jsou sexualita a incestní sexualita zcela 
autonomním motivem. Incestní sexualita sice takto spojuje Valérii s antickou tragickou tradicí, s gotickým románem a s romantickou romancí ${ }^{5}$ (z nichž jsou poslední jmenované samozřejmě ovlivněny tematikou tradice antické). Ovšem na druhé straně tematizuje právě tento druh sexuality též poetika surrealistická - v samozřejmé návaznosti na psychoanalytickou metodu. Tím se přímo dostáváme $\mathrm{k}$ druhé klíčové tradici, která Valérii fundamentálně formuje a která byla až do této chvíle zmíněna jen dílčím způsobem: parodičnost založená na nenadálých kombinacích gotického s profánním vede jak k surrealistické absurdizaci, vzývané Bretonem ${ }^{6}$ v Prvním manifestu surrealismu z roku 1924, tak ke směšnosti a samoúčelnosti vytýčené Nezvalem v předmluvě $k$ Valérii.

Jestliže tedy popsaná parodizace představuje jedno z klíčových spojení mezi Valérií a surreálnou poetikou, specificky tematizovaná sexualita pak toto spojení silně stvrzuje. Surreálná metoda je svými zastánci a priori spojovaná s psychologickým automatismem a s osvobozeným nevědomím; Breton přímo vyhlašuje, že „poesie se rodí z konkrétní iracionality nevědomí“ (BRETON 2005 [1924]: 38). Tento axiom samozřejmě adoptovali i čeští surrealisté, včetně Vítězslava Nezvala. A čeští surrealisté, stejně jako surrealisté evropští, hledali důkazy literárního ztvárnění tohoto axiomu v tradici národní literatury a, stejně jako surrealisté evropští, našli toto ztvárnění v literatuře romantické (která je ovšem svázána s gotickým románem). Nezval sám ve svém příspěvku do sborníku Ani labut' ani Lůna vydaném v roce 1936 platformou Surrealistické skupiny ke stému výročí Máchova úmrtí spojuje poetiku díla tohoto romantického básníka se symboly „latentního sexuálního významu“, které se uvolnily „během procesu jak jen možno uvolněné básníkovy spontaneity automatickým pochodem“ (NEZVAL 2005 [1936]: 31-32). Karel Teige ve svém příspěvku do téhož sborníku hovoři v souvislosti s Májem o volnosti přiznané erotické touhy, „jež opovrhuje káznicí rodiny a manželství a která je funkcí svobody ducha“ (TEIGE 2005 [1936]: 23). Je-li sexuální obrazotvornost projevem osvobození lidského nevědomí, což je vztah, který ustavuje nově zformovaná psychoanalytická teorie, a má-li surrealistická umělecká metoda podobnou intenci jako tato teorie, totiž

5) Ovšem incestní sexualita není jedinou „skandální“ sexualitou, již Nezval ve Valérii z této tradice přejímá. Dalším typem takové sexuality je sexualita (či alespoň pokus o ni) mezi kleriky a řeholníky/řeholnicemi na jedné straně a laiky na straně druhé. Tento druh sexuality najdeme u Lewise (Ambrosius a Antonia), u de Sada (fráteři a Justina) i u Nezvala (misionář a babička, mnich a Valérie). Tato dehonestace celibátu zřetelně souvisí s klasicky romantizujícími motivy gotického románu souvisejícími s negativním vnímáním autority církve $\mathrm{v}$ cestě $\mathrm{k}$ lidské svobodě v poetice surrealistické.

6) Podle Bretona absurdita odhaluje určitý počet „vlastností a faktů celkem vzato neméně objektivních než jiné vlastnosti a fakta“ (BRETON 2005 [1924]: 37). Jako taková je tedy absurdita plnoprávným prostředkem surrealistické, koncept reality podrývající poetiky. 
odkrývání ne-vědomého nitra člověka, ${ }^{7}$ je celkem pochopitelné, že surrealistům imponuje i sexualita incestní a priori tematizovaná touž analytickou metodou. Ostatně, Vítězslav Nezval ve zmiňovaném příspěvku přímo dychtí po tom, aby odkryl incestní sexualitu Máchova díla - s básnickou licencí sobě vlastní tvrdí, že „na napjatém laně mezi oidipským a kastračním komplexem se procházejí v Máchově poesii fantomy všech sexuálních perversí, a uskutečněny v symbolech, sehrávají jedinečnou tragedii“ (NEZVAL 1995 [1936]: 37).

Sexualita pro surrealisty je esenciálně spojena s emancipačním proudem literární tematiky, který směřuje k naprostému osvobození člověka. Surrealisté však chápou tuto svobodu odstupňovaně a její první stupeň představuje právě surrealisty hojně proklamované svrhnutí společenského zla, představovaného sebepotvrzující konvencí moci a pravdy. Ne nadarmo sami surrealisté, kteří spojují toto konečné osvobození s ideály dialektického materialismu, často odkazují na Markýze de Sade, jenž v předmluvě ke své Justině, čili prokletí ctnosti se pokouší poukazem na sociální nespravedlnost oslabit hrot své pornografické fikce: „Může se sice zdát absurdním a nemorálním, líčíme-li přemíru neštěstí, které drtí něžnou, citlivou a ctnost vyznávající ženu a popisujeme-li na druhé straně nejskvělejší blahobyt jiné ženy, která popírala ctnosti celým svým životem, ale zrodí-li se jen jediné zrnko dobra po přečtení těchto příběhů, nikdo nesmí nám vyčítati, že byly nabídnuty veřejnosti“ (SADE 2003 [1791]: 6). Tato idea společenské nespravedlnosti pak souvisí se surrealistickou interpretací Máchy jakožto básníka, který přichází s poezií, v níž se za dějovou kulisou odehrává „boj osamoceného a vytříděného člověka proti společnosti, s níž nechce a nemůže splynout, poesií, jež hoří touhou po svobodě a jež rozvrací společenskou stavbu chtějíc zlomit sociální okovy“ (TEIGE [1936] 2005: 20).

Pro účely rozboru Nezvalova románu však zůstaneme u motivu osvobozené sexuality. I sexualita ve Valérii vykazuje znaky míšení klasických gotických motivů s parodizujícími technikami. To se týká především incestnosti, která se v gotických románech váže především s motivem zamlčeného či nejasného původu: tento prostředek spojený s romantickou strategií nenadálého uspořádání (narovnání) příbuzenských vztahů je ve Valérii variován znovu ad absurdum. Velké množství hypotéz jednotlivých postav o jejich př́ibuzenských vztazích s postavami ostatními znemožňuje odkrytí možných incestních vztahů mezi jednotlivými aktéry: prakticky se dá říci, že až do samotného konce neexistuje

7) V souvislosti s definováním cílů surrealistické metody André Breton vyhlašuje zásadní (téměř mesiášský) epistemologický požadavek: „Tvrdím tedy, že se musíme pokusit zjistit, a to stále jasněji, co se chystá v nitru člověka bez jeho vědomí, i kdyby nám zpočátku zazlíval svůj vlastní neklid“ (BRETON 2005 [1924]: 114). 
pro většinu možných sexuálních vztahů mezi hlavními aktéry Valérie jistota, zda se nejedná o vztahy incestní. Tak Tchoř, který může být Orlíkovým otcem a/nebo Valériiným otcem (ovšem $v$ jisté fázi by mohl být i jejím dědečkem poté, co byl postupně milencem její babičky i matky), se postupně oba pokusí svést; nebo Orlík, ač možný (a nakonec snad i skutečný) bratr Valériin, vyznává se jí ze své sexuální touhy po ní. Tento způsob mnohavrstevného parodování ústředního gotického motivu původu, jeho zamlčení a odhalení, opět podstatně přispívá $\mathrm{k}$ celkové absurditě, iracionalitě a alogičnosti Valérie.

Ovšem připomeňme, že Vítězslav Nezval ve své předmluvě zmiňuje v souvislosti se svou intencí výstavby Valérie ještě jednu kategorii - tajemnosti či tajemství. Je zřejmé, že fenomén tajemna je již z velké části založen $\mathrm{v}$ tom, co bylo dosud uvedeno o zdrojích, z nichž Valérie vyrůstá - $s$ tradicí gotického románu souvisí a priori, se surrealistickým viděním básnické osobnosti projevující se skrze své nevědomí, pak vzhledem k iracionálnímu založení nevědomí, souvisí sekundárně. A právě na tomto švu klasických motivů a postupů pěstování tajemna a nemožnosti racionálního uchopení osvobozeného básnického já je rozehráno tajemno nezvalovské. Hlavní spojnicí prostředkující mezi oběma tajemny je pak sen - opět rozprostřen mezi oběma zkoumanými poetikami. Nezvalův sen, nástroj Prozřetelnosti, který hrdinům gotických románů, zpravidla (alegoricky) vyjevuje důležité skutečnosti o nich samých či o světě, historickém či současném, je zároveň sen tak esenciální pro surrealistické uchopení světa v jeho iracionalitě: jak víme, André Breton v Prvním manifestu surrealismu pomocí snu definuje samu surrealitu. Nejprve prezentuje hyptotézu, že „součet momentů snění [...] není z hlediska času menší než součet momentů reality" (BRETON 2005 [1924]: 22), aby snům a snění přiřkl specifickou hodnotu: „A protože není nijak dokázáno, že ,realita‘, která mě okupuje, tu zůstává, i když jsem ve stavu snu, že se nehrouží do bezpamětna, proč bych nepřiznal snu, co občas realitě upírám, totiž onu hodnotu soběstačné jistoty, která ve svém čase vůbec nepodléhá mému popření?" (IBID.: 23); v posledním kroku konečně přistupuje k definování nové, surreálné reality: „Věrím v budoucí splynutí obou těch stavů, zdánlivě tak protikladných, jimiž jsou sen a realita, v jakousi realitu absolutní, v surrealitu, lze-li tak říci“ (IBID.: 25).

Skutečně s jistou nadsázkou je možné říci, že Valérie je synonymem literárně zprostředkovaného snu, přesněji řečeno směsi vzájemně se prolínajících a překrývajících snů, které jsou neoddělitelné od mimosnové reality: Kde končí Valériin sen? A končí vůbec? A kde začíná realita? A začíná vůbec? V několika dostupných interpretacích Valérie se můžeme explicitně dočíst, že sen končí (nebo začíná) v nějaké konkrétní kapitole. Upřímně řečeno, já jsem žádný takový za- 
čátek či konec snění identifikovat nedokázal - vše splývá, řečeno s Bretonem, v surrealitu, která nezačíná a nekončí, je všudypřítomná, tu více reálná, tu více nad realitou samou.

Ovšem sílu či důležitost snu pro Valérii nevyčerpáme tím, když důkladně popíšeme, jak především motivicky propojuje toto dílo s oběma dosud zmiňovanými literárními či ideově uměleckými tradicemi, dokonce ani tím, když jej budeme považovat za ústřední bod jeho tematické výstavby. Sen zároveň představuje základní podmínku celé narativní struktury Valérie: je principem, jehož implementace do celkové struktury díla umožňuje ukotvit všechny použité významově velice rozkolísané, často vzájemně nekongruentní a místy i narativ samotný podrývající prostředky v relativně sevřený narativní tvar. Nejenom motivy, ale i syžetové uspořádání, předložený příběh, struktura celého díla jsou ikonem snu: od ikonu snu nikdo neočekává tradiční logičnost, racionalitu, kontinuitu, „normálnost“ a právě toto neočekávání se daří Nezvalovi ve Valérii bezezbytku naplnit.

\section{PRAMENY}

LEWIS, Matthew Gregory

1971 [1795] Mnich, přel. F. Vrba (Praha: Odeon)

NEZVAL, Vítězslav

1971 [1932] Valérie a týden divů (Praha: Odeon)

WALPOLE, Horace - REEVOVÁ, Clara - BECKFORD, William - RADCLIFFOVÁ, Ann

1970 Otrantský zámek; Starý anglický baron; Vathek; Sicilský román, přel. E. a T. Tilschovi, H. Skoumalová (Praha: Odeon)

\section{LITERATURA}

BRETON, André

2005 [1924] Manifesty surrealismu, přel. J. Pechar a D. Steinová (Praha: Hermann \& synové)

DIERNA, Giuseppe

1996 „O Valérii, Nezvalovi, Maxi Ernstovi a koláži“, in K. Srp (ed.) Český surrealismus 1929-1953 (Praha: Argo), s. 352-365

1995 [1936] „Konkrétní iracionalita v životě a v dílech K. H. Máchy“, in týž (ed.) Ani labut ani Lưna (Praha: Concordia), s. 29-41 
NEZVAL, Vítězslav (ed.)

1995 [1936] Ani labut' ani Lůna (Praha: Concordia)

SADE, Donatien A. F.

2003 [1791] Justina čili prokletí ctnosti (Praha: Torst)

(1) TEIGE, Karel

1995 [1936] „Revoluční romantik K. H. Mácha“, in V. Nezval (ed.) Ani labut’ ani Lůna (Praha: Concordia), s. $10-28$

TUREČEK, Dalibor

@ 2007 „Epický model Nezvalovy prózy“, Česká literatura 54, č. 6, s. 790-809

Assoc. Prof. PhDr. Bohumil Fořt, Ph.D., amadeus@mail.muni.cz, Ústav jazykovědy a baltistiky FF MU, Brno, Ústav pro českou literaturu AV ČR, v. v. i., Brno, Česká republika / Department of Linguistics and Baltic Languages, Faculty of Arts, Masaryk University, Brno, Institute of Czech Literature of the CAS, Brno, Czech Republic 